\title{
Education and sustainable development in Romania and the European Union countries
}

\author{
Carmen Pintilescu, Dănuț Jemna, Gabriela Pascariu \\ (Faculty of Economics and Business Administration, “Alexandru Ioan Cuza” University of Iasi, Iasi 700506, Romania)
}

\begin{abstract}
The sustainable development supposes a development strategy that would ensure the interdependence and complementarily of objectives from the social, economic and environmental fields. The degree of priority established for the three dimensions of sustainable development differs from one country to another, a fact that confers a national and local meaning to this issue. For the Central and Eastern European countries, balanced economic development represents one of the fundamental objectives of the reforms started in 1990. Education represents a priority of any country's economic development and an extremely important element of economic growth. This paper presents the characteristics of the Romanian educational system while achieving a comparative analysis regarding different countries of the European Union, both from a quantitative viewpoint (using the main indicators in the education field) and a qualitative viewpoint (using student performances in international evaluations). In the end, we present some proposals for the improvement of the present state of the Romanian educational system.
\end{abstract}

Key words: education; sustainable development; Lisbon objectives; data multivariate statistical analysis

\section{Introduction}

Sustainable development means adopting a development strategy that would ensure the inter-dependence and complementarily of objectives in the social, economic and environmental fields. The priority given to the three dimensions of the sustainable development differs from one country to the other, fact which confers a national and local dimension to the issue.

For the Central and Eastern European countries, balanced economic development represents one of the essential objectives of the reforms started in the year 1990. One of the major fields of the economic development policy of a country and one of the most important elements of economic growth is the field of education. Education provides knowledge and skills that facilitate the discovery of better solutions for the economic, social and environmental problems. The United Nations named the period 2005-2014 the 10 years of education for sustainable development, under the wing of the United Nations Educational, Scientific and Cultural Organization

Carmen Pintilescu, professor in the Department of Economics, Quantitative Analysis and Business Information Systems, Faculty of Economics and Business Administration, "Alexandru Ioan Cuza" University of Iasi; research fields: statistics, econometrics, data analysis.

Dănuț Jemna, associate professor in the Department of Economics, Quantitative Analysis and Business Information Systems, Faculty of Economics and Business Administration, "Alexandru Ioan Cuza" University of Iasi; research fields: econometrics, statistics, sampling research.

Gabriela Pascariu, professor in the Department of Economics, Quantitative Analysis and Business Information Systems, Faculty of Economics and Business Administration, "Alexandru Ioan Cuza" University of Iasi; research fields: economics, European integration. 
(UNESCO). In March 2002, the European Council set in Lisbon, as one of the strategic objectives, the transformation of the European Union, until 2010 into the most dynamic and competitive economy of knowledge, capable of sustainable economic growth. In order to achieve this objective each country should adopt measures that would reform the education, taking into account all specific conditions and traditions of each country. For this specific purpose the ministers of education established for the following years very concrete strategic indices that would improve the quality and efficiency of the formation and education systems of the EU countries.

The Romanian institutions and government have shown a vivid interest in aligning university education to the standards set in the Bologna Declaration and in achieving the objectives decided upon in Lisbon. The analysis of the Romanian education system allows the evaluation of the achievement stage of these objectives as well as the appearance of new proposals for the improvement of the actual state.

In order to be able to provide a systemic analysis in the field of education, one should be able to take into account the general context in which the educational act takes place (Scheerens, 2002).

This paper presents the evolution of the main social and economic indices in Romania in the period 1990-2006, namely indices that had a significant influence upon all activity fields and consequently upon the field of education. The specific characteristics of the Romanian educational system are underlined by taking into account the financial, material and human resources specific to this field. Romania's position as compared to other European countries is presented through a quantitative analysis, from the perspective of the most important indices in the field of education, as well as through a qualitative analysis, from the perspective of performances achieved by Romanian students in international evaluations. Using statistic methods of multivariate data analysis, we study the coordinated and the place occupied by the Romanian educational system among other European systems of high education. In the last part we present measures that need to be taken in order to improve the present conditions in the Romanian educational system.

Data statistic processing was made with SPSS software, version 13.00 .

\section{The specific economic, social and demographic context}

The reforming measures adopted by Romania in 1990 for its centralized system has had very important effects on the social, economic and demographic situation of the population.

The structural changes that appeared in economy have determined significant variations of the gross GDP and unemployment rate (Fig. 1).

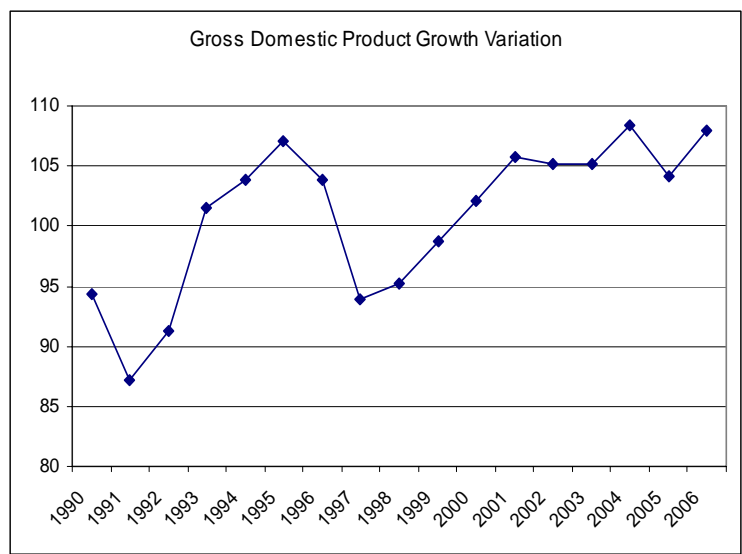




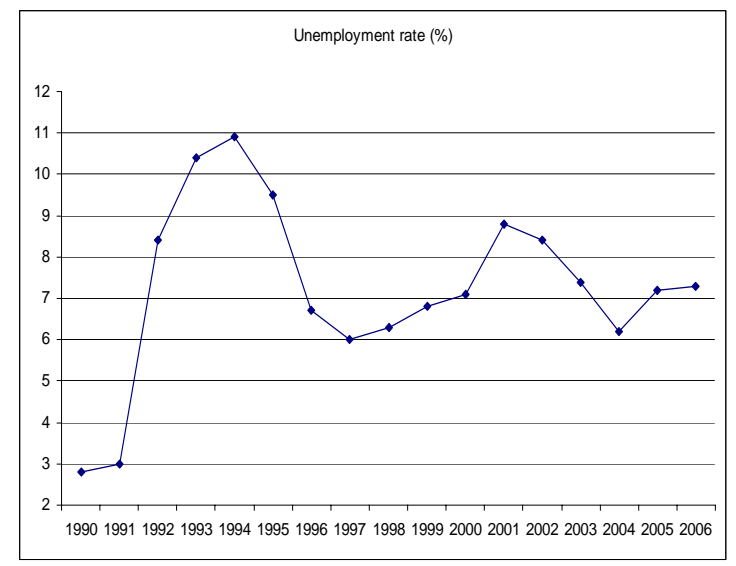

Fig. 1 The GDP growth variation in Romania, in the period 1990-2006

(previous year $=100$ ) and the evolution of the unemployment rate $(\%)$

Data source: The Romanian Statistics Annuary, the National Statistics Institute, Bucharest 2005, 2007, p.132, p.414.

The GDP value had very accentuated variations in the period 1990-2006. The GDP increase was mainly determined by the increase of the domestic demand, within which consumption represented the most dynamic component. After 1997 the GDP value had an ascending trend and a sustained growth due to the increase of the activity volume, which had a direct effect upon the growth of the gross added value, especially in the fields of constructions and services.

Price liberalization measures resulted in the increase of the inflation rate up to $210.4 \%$ in 1992 . After the privatization process of state factories and units was started, the unemployment rate grew rapidly and significantly.

As it can be noticed in the diagram represented in Fig. 1, the unemployment rate in Romania increased from $2.8 \%$ in 1990 to $10.9 \%$ in 1994 . After this year one can notice an irregular evolution, with both increases and decreases. The decrease can be explained by the appearance and development of new activity fields, specific to market economy, such as constructions, trade, financial activities, real estate transactions, etc.

The economic and social factors underlined above have influenced the demographic behavior of the population. The economic and social conditions and the degradation of population's welfare are responsible for the significant decrease of the number of the population and of the natural increase rate in Romania, in the period 1990-2006 (Fig. 2).

The increase of the unemployment rate, the decrease of the natural increase rate combined with the ever increasing migration phenomena caused a decrease of the population number in Romania from 23.2 million inhabitants in 1990 to 21.61 million inhabitants in 2006. The natural increase rate decreased from 3\%o in 1990 to $-1.78 \%$ in 2006.

The economic and social conditions specific to the transition period equally influenced all activity fields. Although education was declared "national priority", this sector was strongly influenced by the effects of the economic decline. 

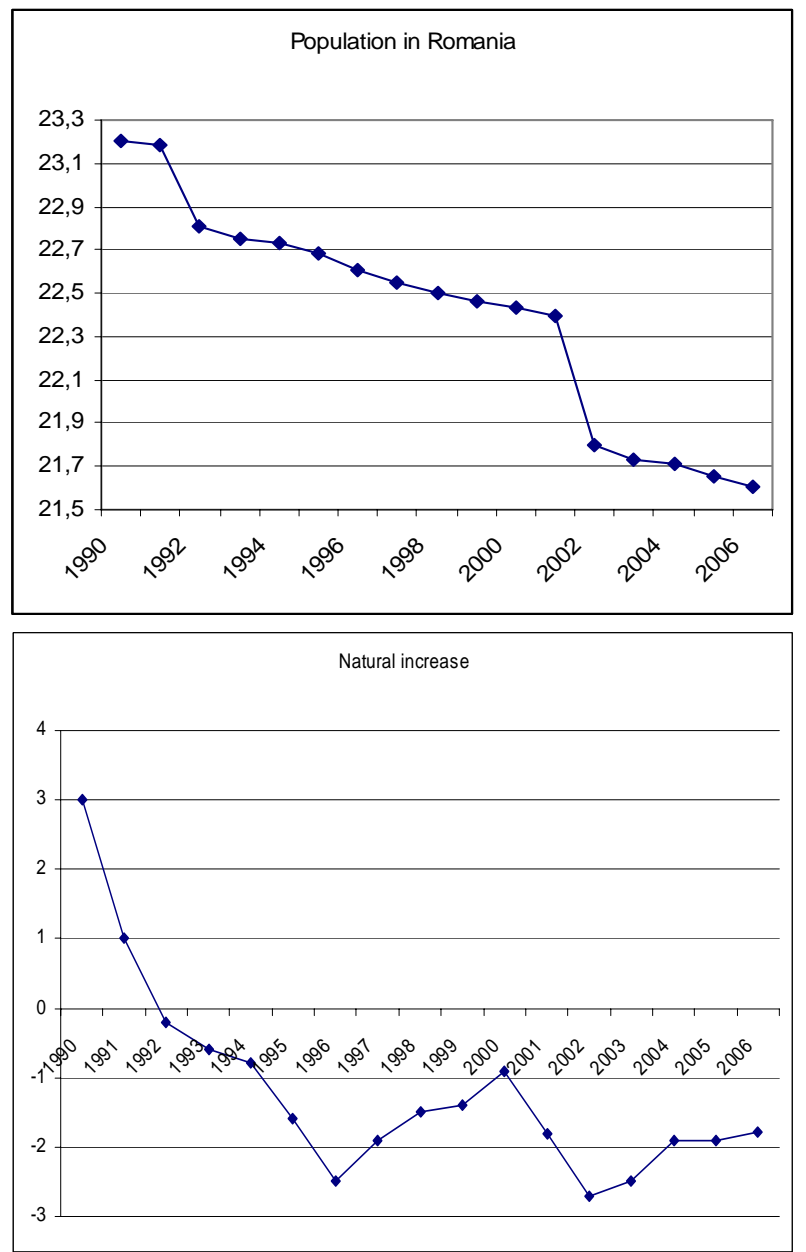

Fig. 2 The evolution of the population (million inhabitants) and of the natural increase rate (\%), in Romania, in the period 1990-2006

Data source: The Romanian Statistics Annuary, the National Statistics Institute, Bucharest 2005, 2007, p.53.

\section{Characteristics of the Romanian educational system}

The characteristics of the present educational system are presented taking into account the financial, material and human resources specific to the field.

\subsection{Financial resources}

The Romanian educational system was directly affected by the economic, social and demographic context created after the 90's. The big variations recorded in the evolution of the gross GDP level in the period 1990-2006 resulted in a chronic under-financing of education (Fig. 3). 


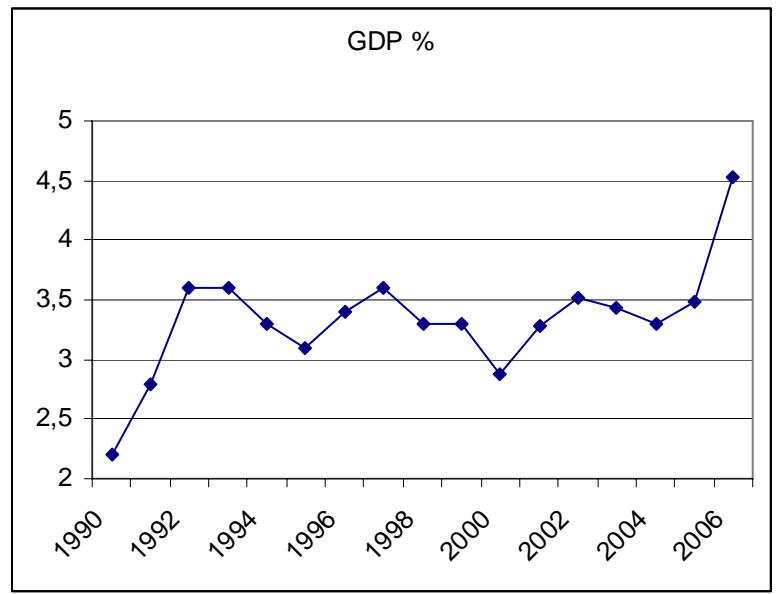

Fig. 3 The evolution of expenditure for education from GDP in Romania in the period 1990-2006 (\%)

As one can notice, the percentage of expenditure from GDP for education was in the period 1990-2006 on average 3.3\% per year. In 2006 the GDP level destined for education increased to $4.52 \%$, but it's still less than the average of EU countries, which is $5.5 \%$. These funds were and still are insufficient for sustaining all activities in a field that was declared "national priority".

\subsection{Material resources}

All investments made for education had variations, their evolution being quite similar to that of the GDP value allocated for education (Fig. 4).

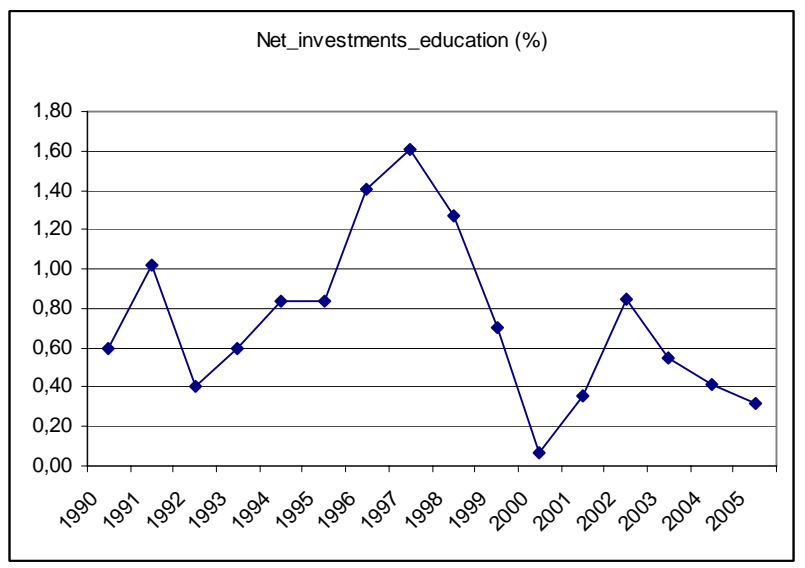

Fig. 4 The evolution of investments achieved in education in Romania, in the period 1990-2005 (\%)

Data source: The Romanian Statistics Annuary, the National Statistics Institute, Bucharest, 2005, P.443.

In the period under analysis, the sums destined to education varied significantly, with ups and downs from one moment to the other. This evolution shows the lack of a strategy of development in long term for this field from the part of public authorities.

\subsection{Human resources}

Human resources involved in the educational process include mainly teachers, pupils and students. In order to analyze the evolution of the number of teachers, pupils and students in Romania, in the period 1990-2006, we calculated the variation of the change of the number of people in the education system recorded every year in comparison with the previous year (previous year=100) (Fig. 5). 


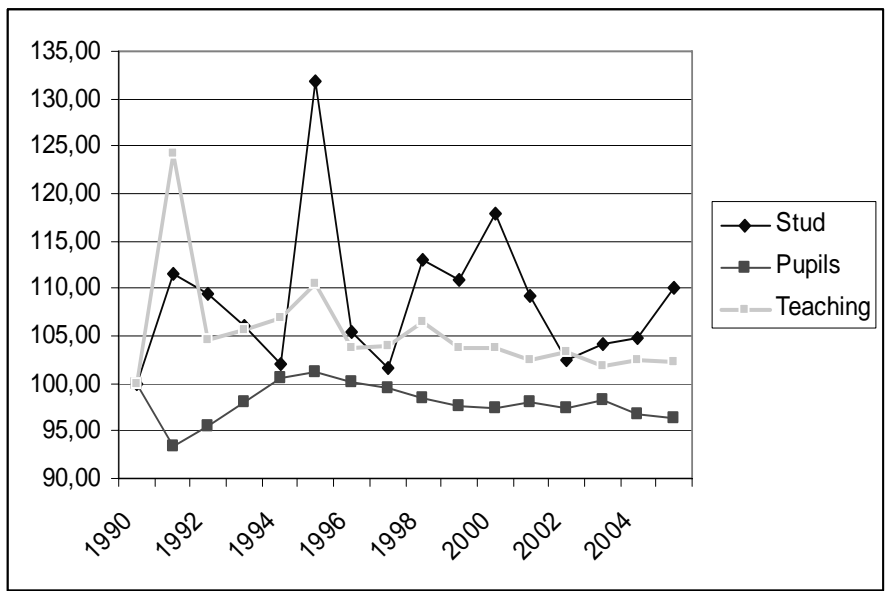

Fig. 5 Change variation of the number of teachers, pupils and students in Romania, in the period 1990-2006 (previous year=100)

The diagram in the figure above stresses that the evolution of the number of teachers was not proportional with the evolution of the number of students and pupils. The changes that occurred after 1990 in the field of education, the appearance of new education forms and the liberalization of university admittance led to important variations in the number of teachers and students in the Romanian education institutions (Fig. 5). Thus, the number of students per teacher increased significantly as far as high-school and university education were concerned.

\section{The comparative analysis of the educational system in Romania and other EU countries in 2006}

The comparative analysis regarding the situation of Romania and that of different countries of the European Union (England, France, Germany, Spain, Bulgaria, Hungary, Poland, Norway, Sweden, Denmark) is made from both a quantitative viewpoint (using the main indicators in the education field) and a qualitative viewpoint (using student performances in international evaluations).

For the comparative analysis of the main indices in the field of education in Romania and other EU countries registered in 2006 we used the following statistic variables: expenses for education from GDP (\%), net enrollment ratio in primary school $1^{1}$, primary pupil-teacher ratio ${ }^{2}$, human development index, research expenditure from the GDP (\%), students in school with computers for students' use (\%). As statistic method of data processing we used the principal component analysis (PCA). The principal component analysis is a method of multivariate statistic analysis of data through which the relations between variables and the resemblances, respectively the differences between statistic units are underlined.

Following data processing regarding certain indices concerning the Romanian and other European educational systems, the following results were obtained:

\footnotetext{
${ }^{1}$ Ratio of children of official school age who are enrolled in school to the population of the corresponding official school age based on the national education system.

2 The number of pupils enrolled in primary school divided by the number of primary school teachers (regardless of their assignment).
} 

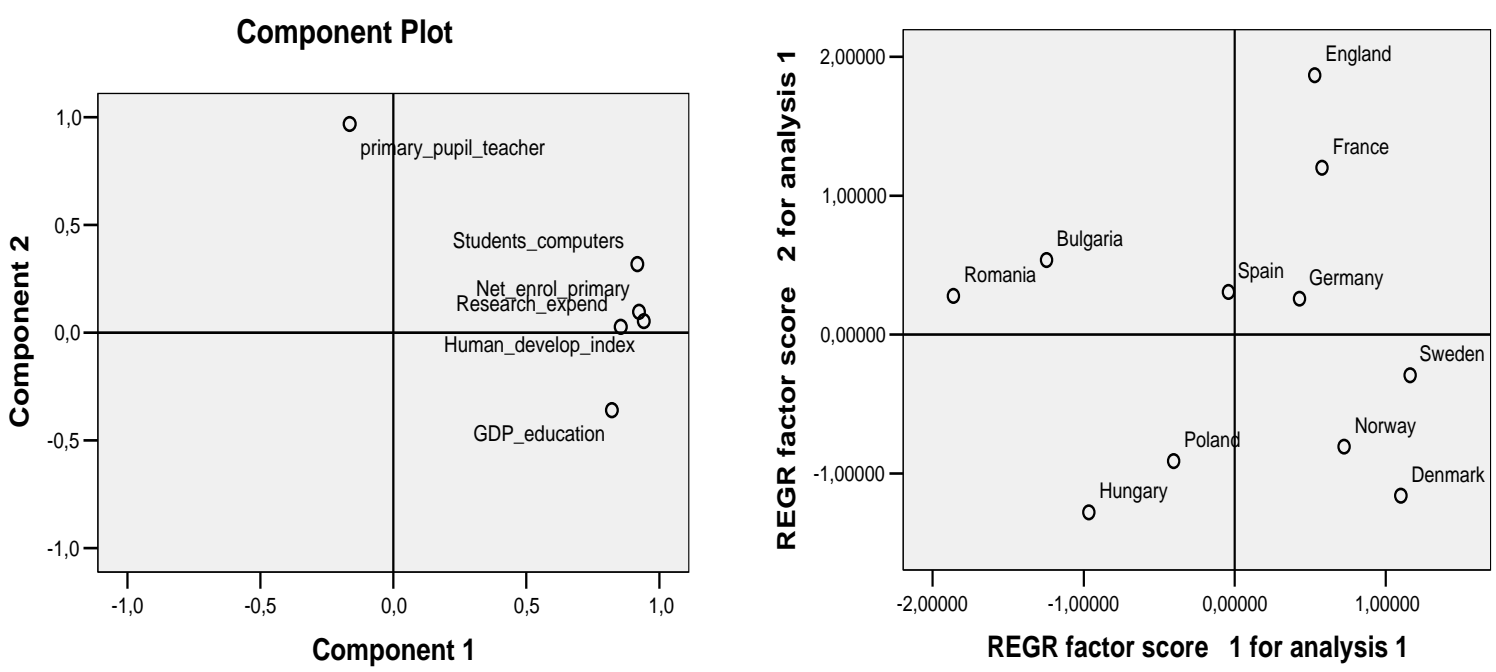

Fig. 6 Graphical representation of variables and countries in the first factorial axes system

The diagrams represented in the figure above show the existence of significant discrepancies between the analyzed EU countries as far as the registered indicators are concerned.

The first factorial axis, represented on the horizontal plan, shows that the most important differences can be seen between Romania and Bulgaria, on the one hand, and Sweden, Norway and Denmark, on the other hand. For the countries in the first group the percentage of GDP percentage allocated to education and research is reduced, the human development index is small and the number schools equipped with computers is fairly modest. The countries belonging to the second group are characterized by the highest values of GDP dedicated to education and research.

The second factorial axis, represented on the vertical plan, underlines the situation of France and England, which have the highest level of primary pupil-teacher ratio.

Taking into account the main strategic indices established in Lisbon, Romania's position in 2006 when compared to the other European countries can be described as follows:

Table 1 The position of Romania and of the other EU countries regarding the strategic indicators established in Lisbon

\begin{tabular}{|c|c|c|c|}
\hline Lisbon indicators & Romania & EU countries & $\begin{array}{l}\text { EU target } \\
(2010)\end{array}$ \\
\hline Premature exit of the education system* & $23.6 \%$ & $14.9 \%$ & Max. $10 \%$ \\
\hline $\begin{array}{l}\text { The percentage of population aged } 22 \text { who are at least high-school } \\
\text { graduates }\end{array}$ & $66.5 \%$ & $77.3 \%$ & Min. $85 \%$ \\
\hline $\begin{array}{c}\text { The percentage of graduates in the following fields: mathematics, } \\
\text { sciences, technology }\end{array}$ & $23 \%$ & $24.1 \%$ & $+10 \%$ \\
\hline The participation of adults in the permanent education & $1.6 \%$ & $10.8 \%$ & $12.5 \%$ \\
\hline
\end{tabular}

Note: * The population aged 18-24 who only graduated a form of inferior secondary education (or less) and do not follow any other form of education or professional training/formation.

Data source: The report entitled The Romania of Education, the Romania of Research, Bucarest, 2007, coordinator: M. Miclea.

As it can be noticed, the values corresponding to Romania are, for most of the indicators, a lot lower than the thresholds established in Lisbon, which should be achieved by 2010. The only indicator where the value is above the established threshold is the percentage of graduates in the fields of Mathematics, Sciences and Technology. This is a fact that shows once again that the present Romanian educational system does not ensure a competitive 
position for Romania in the economy of knowledge.

For the qualitative analysis of the performances attained by Romanian students in comparison with students belonging to other European countries, we have used the results of the international evaluation performed in 2006 by the PIRLS 3 (Progress in International Reading Literacy Study) and PISA ${ }^{4}$ (Programme for International Student Assessment) programmers. The graphical representation of the average scores obtained by the students from different EU countries in 2006 is represented in the figure below:

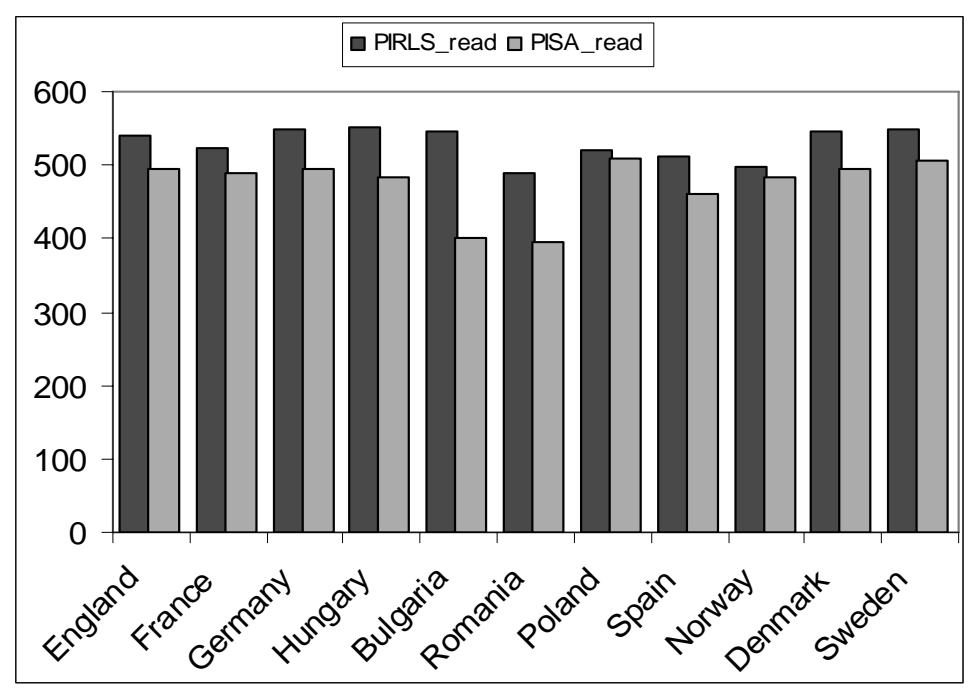

Fig. 7 Average scores obtained at the international evaluations by students belonging to various European countries in 2006

The diagram in the figure above stresses the fact that Romania is characterized by the poorest average scores compared to all the other European Countries that were analyzed, as well as to the Central and Eastern European countries, such as Hungary, Poland and Bulgaria. This shows that the Romanian educational system is inefficient and urgent measures need to be taken in order to improve its quality.

\section{Conclusions and proposals}

The specific Romanian social and economic conditions after the 1990's have influenced all activity fields, education included.

Compared to the other countries of the European Union, Romania is characterized by the most reduced levels of the GDP value destined to education and research. The consequences regarding the performances obtained by students at the international evaluations are proportional to the investments in this field: the Romanian students have obtained the poorest results of all the students in the European countries.

The analysis of the Romanian educational system has underlined the need to adopt urgent methods in order to increase the quality in the educational field and to achieve the objectives set in Lisbon. The most important measures to be taken are the following:

- The increase of the value allocated for education and research, up to $6 \%$ of the GDP. This will result in both the increase of investments in the education system, the purchase of computers for all schools and the

\footnotetext{
${ }^{3}$ The PIRLS Programme evaluates the reading performance of the 6th grade students.

4 The PISA Programme evaluates the school performance of 15 year students.
} 
improvement of the number of students per teacher;

- The stimulation of permanent education through new legislation that would define this objective as a priority. This measure is also imposed in view of the demografic evolution after the 1990's specific to Romania and should lead to the stimulation of education and permanent formation for older people;

- Educating the population with regard to the benefits of taking part in the educational system. Premature exit of the education system will be thus reduced and the participation rate in the education system will increase;

- The increase of the human resources quality in education and the increase of the social prestige of the teacher, both through an increase in wages and the stimulation of innovation and research within the educational system. In 2007, the salary earned by a teacher in the first years was for about 210 Euros per month, less than the average monthly salary in Romania, which is 281 Euros.

The measures for the improvement of the quality of the Romanian educational system must be backed up by analyses regarding the compatibility between the present curricula and the demand on the labour market.

\section{References:}

Carlsson, B, Eliason, G.. (2003). Industrial dynamics and endogenous growth. Industry and Innovation, 10, 435-475.

Drucker, P.. (2001). The next society: Survey of the near future. Economist (online edition), 3.

Everitt, B. S., Dunn, G.. (2001). Applied multivariate data analysis. London: Arnold.

Isaic-Maniu, Al., Mitruț, Al., Voineagu, V.. ( 2003). Statistică, Editura Universitară, Bucureşti.

Kachigan S. (1982). Multivariate statistical analysis. New York: Radius Press.

Miclea, M., (coord.). (2007). Report the Romania of Education, the Romania of Research. Bucarest.

Miron, D.. (2006). Sistemul românesc de învățământ superior între starea de fapt şi deziderate. În: Dumitru Oprea. (Ed.), Partnership in Bologna Process. Experiences and Future Challenges, Editura Universităţii „Al.I.Cuza” Iaşi, Iaşi, 71-90.

Oprea D., Işan, V.. (2006). “Construcția” instituțională a învățământului superior din România. În: Dumitru Oprea. (Ed.), Partnership in Bologna Process. Experiences and Future Challenges, Editura Universității, Al.I.Cuza” Iaşi, Iaşi, 9-53.

OECD. (2006). PIRLS - Progress in international reading literacy study.

OECD. (2006). PISA-Science Competencies for tomorrow's world.

Pintilescu, C. (2002). Analiza datelor. Editura Junimea, Iaşi.

Pintilescu, C. (2007). Analiză statistică multivariată. Editura Universității “Al.I.Cuza” Iaşi, Iasi.

Spircu, L. (2005). Analiza datelor-Aplicaţii economice. Editura ASE, Bucureşti.

Voineagu, V., Furtună, F., Voineagu, M.E., Ştefănescu, C.. (2002). Analiza factorială a fenomenelor social-economice în profil regional, Editura Aramis, Bucureşti.

Voineagu, V., Lilea, E., Goschin, Z., Vătui, M. (2005). Statistică. Teorie şi aplicații. Editura Expert, Bucureşti.

Wonnacott, H., Wonnacott, T. (1991). Statistiques. Economica, Paris.

United Nations Development Programme's Human Development Report, 2006, 283-286.

(Edited by Ann and Emily) 